\title{
Visual Hyperbolism: A Semiotic Analysis of Fast Food Advertisements in South Africa ${ }^{1}$
}

\author{
Kunle Musbaudeen Oparinde \\ Grace Temiloluwa Agbede
}

\begin{abstract}
Public relations agencies are continuously tasked to create exceptional images and elevated narratives to describe the products of fast food outlets. This becomes problematic when it negatively impacts the financial resources and health outcomes of consumers. Using a semiotic approach, this article identifies visual embellishments in South African fast food advertisements. A descriptive analysis of six purposively sampled adverts from South African fast food brands is applied. The advertisements were sampled using three criteria: popularity; patronage and accessibility. The visual embellishments in these adverts are analysed. The authors investigate whether messages in these advertisements fall short of reality, meets, or exaggerates realistic expectations. The research concludes that advertisers apply what is referred to as advertising puffery while attempting to persuade and appeal to the emotions of the customers. This article further recommends that advertising bodies develop guidelines to regulate advertising messages more vigorously to enable consumers to make better informed choices particularly in low income communities.
\end{abstract}

Keywords: deception, exaggeration, puffery, reliability, semiotic approach.

\section{Introduction and Background}

Advertising and other forms of promotional messages are used to sell products and services, as well as promote brand identity. However, consumers today

\footnotetext{
${ }^{1}$ This article is being co-published with Interdisciplinary Journal of Economics and Business Law with minor changes to fit the requirements of Alternation. Cf. Oparinde and Agbede (2019) for the full reference.
} 
find it increasingly difficult to dismiss the likelihood of 'misinformation' commonly used in visual materials for emphasis. It is argued that the use of hyperbolic expressions in adverts have become a common phenomenon. Barbu-Kleitsch (2015:176) substantiates this claim by arguing that advertisements are 'laden with strong rhetoric enabled through visual tropes and figures to awaken the public's interest in consumption of the objects'. In as much as this is the objective of an advert, it becomes problematic when they are exaggerated and thus have negative consequences or potential to do harm. Such consequences may be from a financial or health point of view. Amyx and Lumpkin (2016) also acknowledge that the effects of puffery in advertising may adversely affect consumers' opinions about an ad industry. They proceed to note that exaggerated advertising may not only have negative effects on the consumers but in fact may also be harmful to the reputation and perceived integrity of brands. Chakraborty and Harbaugh (2014) observe that advertisers engage in the use of puffery to influence purchase intentions.

Scholars have written about the impact of hyperbolic expressions in adverts on consumers in various industries. Yet, this is the first attempt at analysis of South African fast food brands particularly. The intention of the authors is to focus on fast food brands' advertisements, predicated on the assumption that fast food outlets rely on the context of 'hunger' in their advertisements. According to Merriam-Webster (2016) dictionary, having an uncomfortable feeling in one's stomach because one needs food implies hunger. This may not be a debatable issue especially considering the prevalence of hunger and poverty in Africa. It is thus anticipated that advertisers, on the one hand, may hinge on exaggerated messages to attract as many customers, mainly in low income bracket, who have been plagued by the severity of hunger. Advertisers, on the other hand, may use overstated information to persuade low income earners with poor knowledge of food and limited choices, to buy their products, thereby exacerbating hunger and contributing to poor health outcomes.

Dike (2015:449) had earlier observed that poverty and hunger are the gravest challenges facing the African continent in the 21 st century. About onethird of the African population live below the United Nations poverty line of 1.5 dollars per day. It is thus clear that issues of poverty, hunger and famine are endemic to Africa. South Africa in particular, among many other countries, also pledges to eradicate poverty and hunger by integrating the Sustainable Development Goals (SDGs) agenda aimed at ending poverty and ensuring that 
people enjoy peace (Dhlamini 2017). Consequently, fast food advertisers can easily exploit the situation in promoting exaggerated adverts mainly through visual means in South Africa. An assertion also supported by Huat (2017) in Malaysia that exaggerated fast food print advertisements increases attention, creates favourable judgment and motivates a purchase among the consumers. However, that all necessary aspects have been researched remains a mirage. Unlike some other studies, this study dwells on visual hyperbolism in South African fast food brands adverts - a domain which has received little or no reference from academics in South Africa. In this regard, evidences of visual puffery or deception from fast food advertising are examined.

Scholars, recently, in one way or the other, have dwelt on the impact of the visual elements of advertising. At the same time, there are some seminal works that have contributed enormously to the field by contextualizing hyperbolism in visual advertising. For McQuarrie and Phillips (2005:7), they observe it as a visual metaphor. They agree that for many years now, 'metaphors and pictures in adverts may be unusually powerful persuaders which could readily be turned to deceptive purposes'. This is a suspicion they have, in fact, noticed before their research. For Callister and Stern (2007), they consider their opinion as a hyperbole. Both presenting the argument that an advertisement can affect the way an advertising message is processed and perceived by the viewer. According to Nagler (1993), deceptive advertising occurs when a stable misrepresents to the buyer the qualities of the promoted product and consequently the anticipated utility from retaining the product.

Today however, consumers are increasingly warned against such practices especially by consumers' protection agencies, which leave them less vulnerable and increase their perception of deception (Chaouachi \& Rached 2012:1). Sadly, consumers with access to such messages might be mostly in the middle to higher income markets with access to the media, while people in low income markets might not have such access. Increasingly, fast food brands have continued to exaggerate their products, although this indirectly undermine their potential to grow brand loyalty by creating skepticism among consumers. In an age where consumers compare opinions with other consumers to verify suspected misinformation of the simplest things, today's consumers demand blanket transparency and authenticity in advertisements so that they may impart logical feedback in terms of soliciting their acceptance or rejection of a marketing campaign aimed at influencing their buyer behaviour.

Barbu-Kleitsch (2015) note that one of the visual devices that is some- 
how neglected, yet enjoys wide popularity in today's ads, is hyperbole. He considers the use of outlining people, products, and objects in ways that far exceed their abilities as a form of hyperbole. That advertising involves common strategy used to capture attention and emphasise emotions or product attributes implies that visual hyperboles can indeed be perceived as an instance of advertising puffery. As a result, the consumer has to understand the hidden meaning of an advert. Parsa (2015) finds out that advertisers use images to sell everything. He recognizes the fact that images play enormous roles in the style of the adverts. This is in fact similar to Akpan and Obukoadata's (2013) study that there is often a dominance of symbolic values in advertisements. Noting that symbols in advertisements have enormous effects on consumers. Their study highlights the fact that visual inputs in advertising are relevant to contemporary promotional strategies and that the inclusion of semiotic appraisals as a component of advertising is very important to the effectiveness of adverts. Evidently, advertisers make use of non-linguistic or graphitic devices to embellish and interpret their language.

Tahmasbi and Kalkhajeh (2013) carried out a critical discourse analysis of Iranian banks advertisements. They are interested in the manipulative ways - the social and power abuse embedded in adverts. One line of accordance with our research is that adverts have powers to manipulate and maybe misinform. Kaur, Arumugam and Yunus (2013) also note that advertising uses visuals as a powerful tool to shape people. In Agbede's (2016) study, the importance of symbols and images in advertisements also suffice. It was found that text only might not be enough to attract customers, but when used together with images, pictures and symbols; they show the context of the advertisement. Advertisers often match texts and images together effectively. Akinbode (2012:27) concludes that 'advertising messages are always regarded as communication designed by the sender to produce certain forms of reaction, behaviours or attitude from the receiver of the message'. Kannan and Tyagi (2013:1) in another study also notes that in the bid to make adverts fascinating, exciting, imaginative, and in a creative manner; the colour, background, symbols, and the visual displays in the advert must be attractive. It is within the above review tendencies that we aim to examine the instances of exaggeration in South African fast food brands advertisements. This study also hopes to create a public awareness for consumers on the issue of hyperbolism in South African fast food brands' adverts. Consequently, this article aims to alert advertising bodies to develop stringent rules to guide against puffery in advertising. 


\section{Methods}

The authors adopt a systematic review approach. Several examples occurred from the search, but this paper focuses on only six adverts selected across three of the biggest fast food brands in South Africa, basically in terms of their popularity, patronage, and accessibility. These criteria were derived from Business Tech's list of the biggest fast food franchises in South Africa in 2017. The brands include; McDonald's, KFC, Nandos. Six adverts were purposively selected based on their relevance to this study. These visuals were extracted from searches on the worldwide web. We analyse two advertisements from each brand as this is manageable for the researchers and the study. It is believed that the semiotic analysis of the selected data will suffice for this paper.

\section{A Semiotic Approach}

Employing a semiotic approach, this paper intends to investigate how South African fast food brands utilize visual hyperbolism in their adverts. It has so far been established that advertising messages are filled with persuasive symbols. In this section, we clarify the theoretical position guiding this study. Semiotics is often considered as the study of meaning-making through signs. Bouzida (2014) considers semiotics as a field that studies the life of signs within society. In analyzing the data from this study, Roland Barthes approach to semiotic analysis comes to mind.

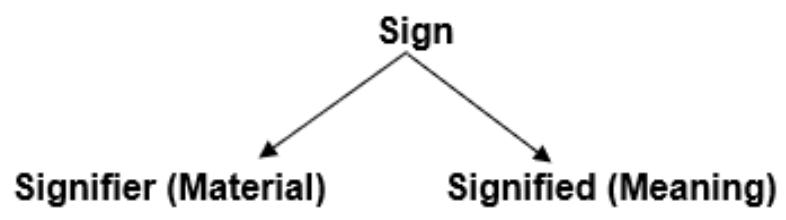

In Roland Barthes (1968) principle, a landmark in the field of semiotics - the image is related to the aesthetic and ideological factors that are opened to readings and interpretations at the connotative level in order to explain how meaning is created through complex semiotic interaction. As such, various components such as images, adverts, colour, and films could be elements of meaning-making. Hence, Barthes favours the interpretation of text by the recipient as superior to intention of the text-producer in what he refers to as the death of the creator because the receiver can now understand, interpret and produce a wide range of meanings from the source text. In Roland Barthes 
view, he is interested more in 'how' things mean rather than 'what' things mean. Barthesian analysis can then be carried out based on the diagram above.

The signifier is the object of analysis such as images, pictures or symbols, signs and so on. The signified is not a thing but the mental representation of things and the outside world, it has a psychological and abstract nature that is given through denotation (Bouzida 2014). The Barthesian semiological approach proposes two holistic levels in analyzing an image. In describing the data, the researcher needs to analyse denotatively and then connotatively. Put simply, the first level analyses the data according to the literal meaning of the sign. It basically gives the obvious description of what we observe from the data. The characters, symbols, colour, design among others are tested here. On the other hand, connotation is the second-order parasitical meaning. Here, the image is subjected to different explanations that are often influenced by the socio-cultural perspective of the semiotic analyst. Here, the analyst neglects the obvious meaning of the text and tries to pronounce the hidden meaning of the text. This approach can prove very useful in exposing puffery in advertising. For some, a hamburger may represent an epidemic of obesity, while for others; it may be viewed as a tasty nourishing meal (Serva 2017). Such is the power of symbolic expressions. How recipients view and analyse adverts is largely dependent on their understanding of the society in which they live. In this section, we attempt an analysis of six selected adverts from three of the biggest fast food brands in South Africa namely: McDonald's, KFC and Nandos. The examinations are done bearing in mind Roland Barthes principles of conducting a semiotic analysis as discussed above.

\section{The Power of Symbolic Expression in Fast Food Adverts: An Analysis}

In this section, we attempt a descriptive analysis. The authors adopt the framework of Fell and Lukianova (2015) in analysing selected adverts. The analysis of these two authors of images focused on shape, colour, texture, accessibility, social context, etiquette, and attitude to food. We adopted some elements of this framework and we added some new elements namely: attitude to advert and lexical items or symbolic expressions. This is done to streamline the framework to the objectives of our study as the work of Fell and Lukianova is fundamentally different from the topical study. They were more interested in analyzing the imagery of how food consumption takes place in public. 


\section{McDonald's Advertisements} BURGER KING WHOPPER

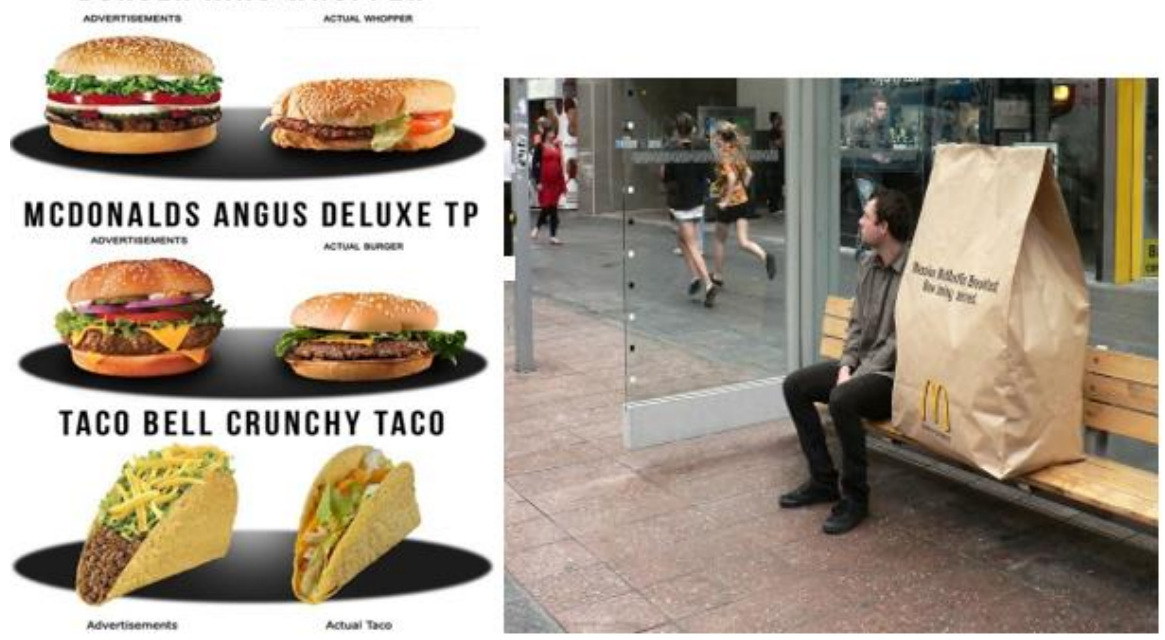

Figure 1: McDonald's adverts retrieved from the internet:

https://www.google.co.za/search?q=mcdonalds+exaggerated+adverts\&source $=\operatorname{lnms} \&$ tbm $=$ isch \&sa $=$ X\&ved=0ahUKEwi0_sCB7_nWAhWZF8AKHTzDB zsQ_AUICigB\&biw=1366\&bih $=662$

\begin{tabular}{|l|l|l|}
\hline \multicolumn{1}{|c|}{ Framework } & \multicolumn{1}{|c|}{ A } & \multicolumn{1}{c|}{ B } \\
\hline Shape & Rounded & Pentagon. Solid at the root. \\
\hline Colour & $\begin{array}{l}\text { Clear, attractive, and } \\
\text { visible. }\end{array}$ & Neutral and abstract. \\
\hline Texture & Simple and clear. & Concrete. \\
\hline Social context & $\begin{array}{l}\text { Poster advertisements } \\
\text { meant for consumers to } \\
\text { see McDonald's } \\
\text { products. }\end{array}$ & $\begin{array}{l}\text { Perhaps a train or bus park. A } \\
\text { busy environment. Seems to } \\
\text { be an affluent environment. }\end{array}$ \\
\hline $\begin{array}{l}\text { Attitude of } \\
\text { advertisements }\end{array}$ & $\begin{array}{l}\text { Advertisements differ in } \\
\text { size from actual product. }\end{array}$ & $\begin{array}{l}\text { Puffery intended. Bag bigger } \\
\text { than the buyer. }\end{array}$ \\
\hline $\begin{array}{l}\text { Symbolic } \\
\text { expressions }\end{array}$ & $\begin{array}{l}\text { Exaggerated. E.g. King } \\
\text { and Deluxe. }\end{array}$ & $\begin{array}{l}\text { Exaggerated McDonald's } \\
\text { brand identity. Oversized bag } \\
\text { as a representation of how } \\
\text { gigantic Mcdonald's is. }\end{array}$ \\
\hline
\end{tabular}




\section{KFC Advertisements}
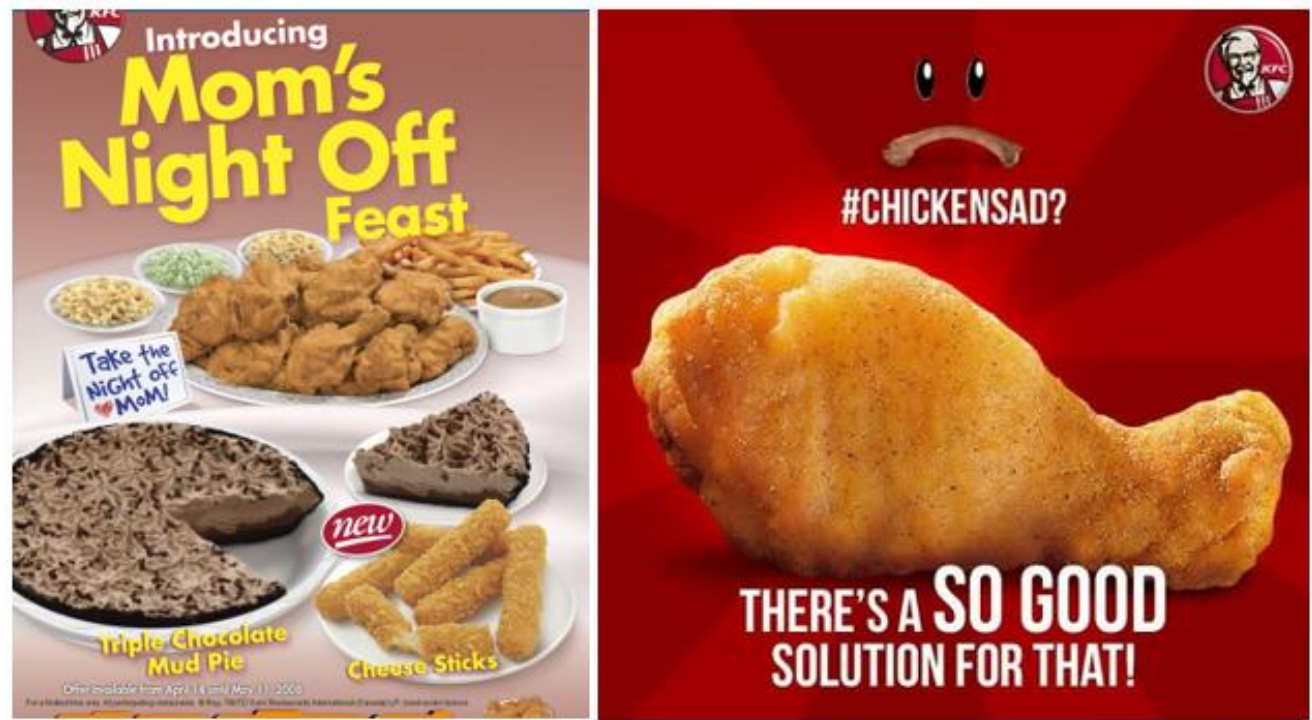

Figure 2: KFC adverts as retrieved from the internet:

https://www.google.co.za/search?biw=1366\&bih=662\&tbm=isch\&sa=1\&q=

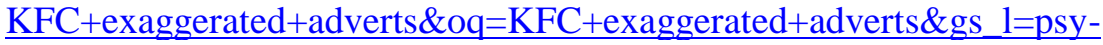
ab.3...11293789.11298590.0.11299138.0.0.0.0.0.0.0.0..0.0...0..1.1.64.psyab..0.0.0...0.S0DPS jpNlo\#imgrc $=\mathrm{dZwE} 8 \mathrm{R} 0 \mathrm{yczUeaM}$ :

\begin{tabular}{|l|l|l|}
\hline \multicolumn{1}{|c|}{ Framework } & \multicolumn{1}{c|}{ A } & \multicolumn{1}{c|}{ B } \\
\hline Shape & Solid and diverse. & Big, gigantic, expanded. \\
\hline Colour & $\begin{array}{l}\text { Flamboyant, eye-catchy, } \\
\text { attractive, and visible. }\end{array}$ & $\begin{array}{l}\text { Active, and stimulating } \\
\text { and intriguing. }\end{array}$ \\
\hline Texture & $\begin{array}{l}\text { Sharpening: instant } \\
\text { understanding of the advert. } \\
\text { Urban. Patterned. }\end{array}$ & Ripe and intense. \\
\hline Social context & $\begin{array}{l}\text { Enough for the family to } \\
\text { feast on. }\end{array}$ & $\begin{array}{l}\text { Excitement - an end to } \\
\text { hunger. Huge drumstick. }\end{array}$ \\
\hline $\begin{array}{l}\text { Attitude of } \\
\text { advertisements }\end{array}$ & $\begin{array}{l}\text { Can feed more than one } \\
\text { person. }\end{array}$ & Solution to hunger. \\
\hline $\begin{array}{l}\text { Symbolic } \\
\text { expressions }\end{array}$ & Family size. Plentiful. & $\begin{array}{l}\text { Huge. Solution to hunger. } \\
\text { Unbelievably filling. }\end{array}$ \\
\hline
\end{tabular}




\section{Nandos Advertisements}
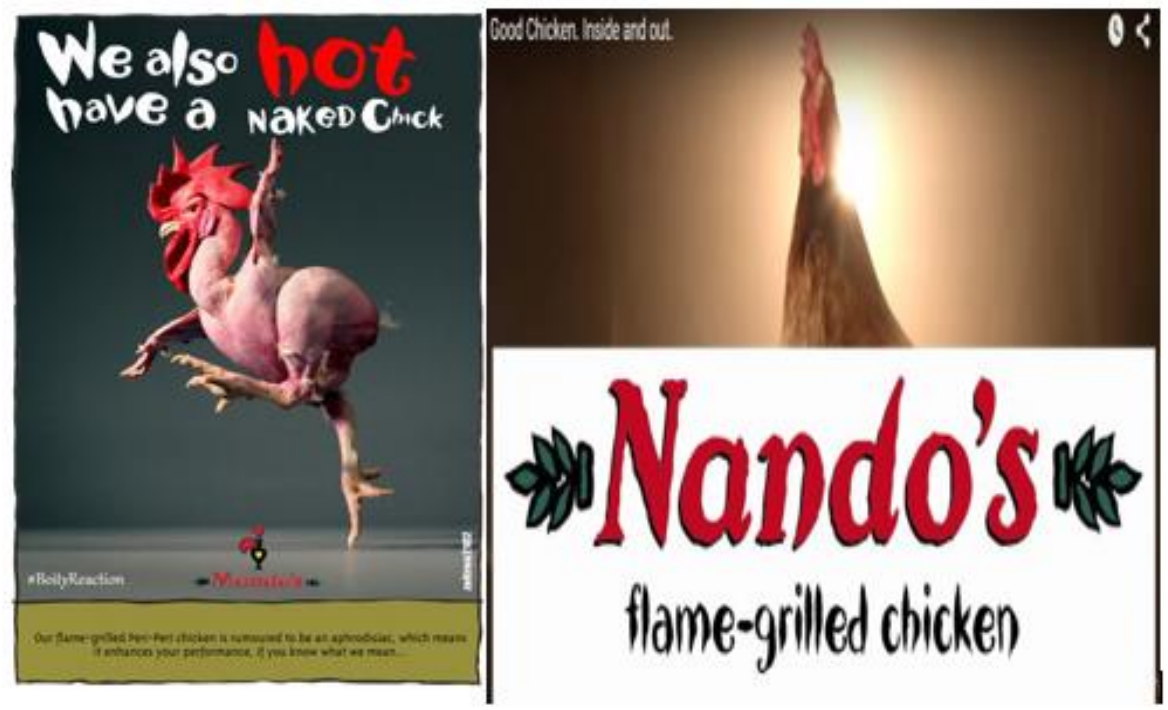

Figure 3: Nandos advertisement as retrieved from the internet: https://www.google.co.za/search?biw=1366\&bih=662\&tbm=isch\&sa=1\&q= nandos+adverts\&oq $=$ nandos+adverts\&gs_l=psyab.3...41061.41648.0.42374.0.0.0.0.0.0.0.0..0.0....0...1.1.64.psyab..0.0.0....0.rOMCGDvnLCs\#imgrc=7W0HM616LnxsWM:

\begin{tabular}{|l|l|l|}
\hline \multicolumn{1}{|c|}{ Framework } & \multicolumn{1}{c|}{ A } & \multicolumn{1}{c|}{ B } \\
\hline Shape & Free standing figure. & Free standing figure. \\
\hline Colour & $\begin{array}{l}\text { Cool, represents } \\
\text { movement and progress. }\end{array}$ & Brightening and clear. \\
\hline Texture & Powerful and intense. & Light and shadowy. \\
\hline Social context & Sensual. & $\begin{array}{l}\text { Deceptive - life chicken that } \\
\text { has not been grilled yet. }\end{array}$ \\
\hline $\begin{array}{l}\text { Attitude of } \\
\text { advertisements }\end{array}$ & $\begin{array}{l}\text { Advertisements meant for } \\
\text { consumers preferably } \\
\text { males who are easily } \\
\text { enticed by female species }\end{array}$ & $\begin{array}{l}\text { Symbol of chicken and text } \\
\text { are confusing. Picture of } \\
\text { chicken has not been flame- } \\
\text { grilled. }\end{array}$ \\
\hline $\begin{array}{l}\text { Symbolic } \\
\text { expressions }\end{array}$ & $\begin{array}{l}\text { Sexual: Hot naked } \\
\text { chicken. }\end{array}$ & Dazzling and glowing. \\
\hline
\end{tabular}




\section{Discussions}

In the above advertisements, there are impressive displays of some fast foods advertisements. There is also a case of an oversized bag that is bigger than the buyer. Virtually in all cases, the brand name or symbol of each of the brand is present in the advertisements. This, of course, creates a symbolic impression in the mind of the customers who are aware of and interested in the products of such brand. Brand identity has become a very important driving force of customer loyalty (Zhang 2015). Arguably, the impact of brand image has a huge impact on customer loyalty.

In all, the advertisements are used to create an impression that resonates with the social identity of the consumers mainly in terms of 'hunger'. Repeatedly, the world is gradually moving towards the visual direction. As such, people tend to give more attention to visuals filled with meaning than they do with written texts. This however does not mean that texts do not have values any longer. But there is no doubt that what people see can have an enormous effect on their judgement as in the above advertisements. It may be interesting to note, first of all, that the kind of names given to these products have some powerful implications especially in Africa where people associate with flamboyant and maybe, good-looking materials. Hence, having such names as 'kings' and 'deluxe' have a sense of prestige for the consumers who automatically translate the words as reality. The realness of these words may later be ascertained when one compares the advertisements with the actual product. It is however noteworthy that some consumers are very brand loyal and therefore are not really influenced by hyperbolic advertisements and promotions.

The advertisements appeal to the emotions of a man who is hungry and requires better quality fast foods to quickly conquer the hunger. There are displays of burgers, chickens, chocolate, among others, that may not remain the same in the actual product. This is indeed an act of puffery by the brand to present. It could also be a misleading way of also saying that their products are affordable, so much so, that one can buy such a large amount. Fell and Lukianova (2015) also agree that consumers perceive and process these images instantly, immediately and irrationally when drawn towards the attractive and colourful fast food imagery. In another data, we observe an oversized McDonald's bag. Fell and Lukianova (2015) indeed acknowledge the ability of fast food brands to act as an agency interested in freeing us from hunger. In 
Danciu's (2014) study, he recognizes what he refers to as deceitful advertising, which uses facts, but deceptive facts that in turn confuses, misleads, or employs blatantly untrue statements when promoting a product.

While it is true that someone may not necessarily take these exaggerated advertisements seriously, it is also true that it may influence the decision of someone who is hungry or starving especially in the low-income bracket. This is what Barbu-Kleitsch (2015:178) considers as puffery in advertising. He says that 'advertisers use puffery - exaggeration and hyperboles - to get people's attention and make their message notable. Because the claims in advertising puffery are obviously amplified, and because exaggeration works to get people's attention, puffery is an accepted and highly used advertising technique'. In Danciu's (2014) words, he refers to the act of puffery as exaggeration of quality. This is also what Toncar and Fetscherin (2012) refer to as exaggerated or unsubstantiated advertising claims. This is highly true of South Africa where there are varieties of food for people to choose from. Fast food brands will thus try their possible best to attract as many customers as possible while exploiting the context of hunger in consumers. Heath and Chatzidakis (2012) further opine that where people are being misled or deceived, it does not enthuse belief or whatever good in the upcoming.

Not only have customers become more demanding, they want authentic products (food) and services tailored to their specific needs and wants. Customers today want superior value, which they define as high-quality products that are competitively priced and supported by excellent customer service. Hence, puffery may damage attitudes toward the ad among those who would normally be more receptive to the message (Amyx \& Lumpkin 2016). They often deviate from real expectations to arouse the interest of consumers. This resonates with Danciu's view that (2014:27) 'many advertisements which are placed in practically all media rely on visual and combined techniques to manipulate the consumers'. Some of the most used techniques are the manipulation by photo shopping, the mixture of amusement with ads, the manipulation of the size and the price of the product and the misleading graphs. Examples of advertising that falls in the category of hyperbole includes anything from creative billboards, posters to oversized brown paper bags aimed at deceiving the customers.

Fast food brands that stand out from the rest are fixated on continual improvement, to the point of being obsessive in their quest to sustain a solid reputation. However, some South African fast food brands still have a lot to 
learn from their global counterparts; the reason international eateries are clearly flamboyant in the décor and furnishings they use to single out their particular brand identity - as well as the quality of food offerings on their menu's - is because they cater for a cosmopolitan palate. Nowadays, people eat with their eyes; it starts with the ambience, their interaction with the restaurant staff, and the way signature dishes are 'sold' by way of an enthusiastic explanation in the absence of good quality authentic visuals in the print menu. Consequently, consumers have become desensitized to blatant exaggerations, thus causing the target audience to view the image and message with distrust. Khan and Rajput (2014) also note that deceptive advertising is a controversial matter and literature suggests and confirms that, even though advertisers may disagree. They agree that false claims and exaggerations in an advert is considered deception while promoting and campaigning for the products and services. Moreover, it is apparent that the advertisers, who do not mislead their customers, always enjoy market shares more than those who exaggerate. They thus recommend that advertising companies should not focus on making false claims with deceptive advertising. Advertising should be focused on the level of competitive services to generate positive customer attitude and behavior towards the advertised product or service.

It is crystal clear that fast food outlets want to make profits at all cost. Not only do they keep their brand identity prominent in all their advertising materials, they also develop different strategies in an attempt to attract as many customers as possible. As such, hyperbolic effects are employed in the advertising materials. It is also interesting to note that they often consider their target audience. A common feature of the target audience is 'hunger' as exemplified in the analysis. While this may prove profitable for advertisers, it does not augur well for the consumers.

\section{Recommendations}

Since business owners or managers are focused on providing excellent customer service, their advertising promises must match up with the product or service provided. However, when customers' high expectations fall short, they will likely rate their experience as less than satisfying. In the same vein, when delivery of services exceeds expectations, customers may assume the role of ambassador of the fast food brand. Not only will they come back to frequent the establishment, they will also broadcast their experience. This 
implies that consumers in general are critical of visual images that do not correspond with reality. In his Manipulative marketing: persuasion and manipulation of the consumer through advertising, Danciu (2014:32) advocates for the need for advertisers to be more authentic in that all communication with the consumers should be hundred per cent honest and transparent. His argument is hinged on the belief that an increasingly higher proportion of consumers are prizing the transparency, accountability and authenticity of adverts.

Among earlier recommendations in literature, Fyock (2011) suggests that advertisers should use visual hyperbole with caution as it could cause negative judgments of deception, confusion and alienation. As such, advertisers should align their messages with consumers' values in every aspect and in all components of advertising as the companies which align their values with their actions, will earn enduring loyalty among the consumers. Khan and Rajput (2014) also recommend that advertising companies should not focus on making false claims with deceptive advertising.

In the current study, the authors recommend that there needs to be a body in charge of regulating adverts; and such a body needs to be strict in terms of avoiding deliberate deception or puffery in advertising. From the above analysis using a Barthesian approach, one is able to understand the exaggerated features of an advert based on the perception of the viewer. Advertisers should be guided by stringent ethics clearly identify what is acceptable and unacceptable in advertising. Furthermore, advertising should be focused on the level of competitive services to generate positive customer attitude and behavior towards the advertised product or service. As such, there is the urgent need for bodies to instantly rise to the rights of the customers by maintaining certain guidelines and ethics that could perhaps create a reduction in the use of puffery by advertisers.

\section{Conclusion}

This paper has demonstrated that symbolic expression has the power to affect us both mentally and physically. For example, a persuasive message that is honest, insightful, unapologetic and inclusive has a positive long-term effect on consumers' buyer behavior. The premise is for the marketer to avoid hyperbolism and being gimmicky; the $21^{\text {st }}$ Century consumer prefers relatable images to staged food shots. This approach to 'show it as it is' means fast food 
outlets and fast food brands may need to follow through their justifiable perception of authentication by producing food that realistically exemplifies the actual food presented to the customer. Yet, many consumers are unwavering in their loyalty to a particular food establishment or foodservice brand that they do not question even outrageous misinformation-advertising campaigns. Fast food brands have continued to deliver messages of providing juicy, delicious and delectable foods to its customers through the effective use of a visual hyperbolism in their advertisements.

This paper has examined the hyperbolic nature of visual embellishments in South African fast food advertisements from a semiotic point of view. We have been able to supplement existing literature by exposing puffery in advertising while focusing on South African fast food brands only. The research suggests that further studies should be conducted on not only fast food brands but also on other advertising systems and should particularly focus on one society. Also important is for further studies to actualize whether customers' anticipations are met after considering fast food brands advertised products. In the process, we have actualized the instances and possible effects of customer manipulation on fast food brands.

The paper provides information on how customers interpret visual embellishments in adverts. The paper notes that fast food outlets rely much on the context of hunger to advertise products, thereby, exaggerates pictures or images. The paper also identified the necessity of maintaining good customer relationship and as a result, customers not perceiving adverts from fast food brands as deliberately misleading. The paper further provides recommendations to regulators on new and creative ways of avoiding puffery in advertisements. While creativity is important in advertising, manipulative creativity may in fact cause more harm to the fast food brands than good. Like other studies, this study also suffers a great limitation in that it was solely conducted through a desk approach. Otherwise, some more interesting examples and information may have added more quality to this study.

To conclude therefore, I believe that regulating bodies can also be useful in this regard. Through a critical semiotic analysis, adverts that are mainly developed to deceive can be identified. 
Kunle Musbaudeen Oparinde \& Grace Temiloluwa Agbede

\section{References}

Agbede, G.T. 2016. Stylistics in Advertising: A Comparative Analysis of Selected Bank Advertisements in Newspapers and Magazines from South Africa and Nigeria. Durban University of Technology, Masters Dissertation.

Akinbode, O. 2012. A Sociolinguistic Analysis of Advertising Language in Selected Nigerian Mass Media Commercials. Research on Humanities and Social Sciences 2,8: 26 - 32.

Akpan, I., E.E. Akpan \& P. Obukoadata 2013. A Semiotic Deconstruction of Symbols in Print Advertising Contents: Implications for Consumers

Purchase Decisions in Nigeria. Research on Humanities and Social Sciences 3,13: 13 - 25.

Amyx, D.A. \& J.R. Lumpkin 2016. Interaction Effect of Ad Puffery and Ad Skepticism on Consumer Persuasion. Journal of Promotion Management 22,3: 403 - 424. https://doi.org/10.1080/10496491.2016.1154920

Barbu-Kleitsch, O. 2015. Use of Hyperboles in Advertising Effectiveness. International Conference of Redefining Community in Intercultural Context, Brasov, 21-23 May 2015.

Barthes, R. 1968. Elements of Semiology. New York: Hill and Wang. Bouzida, F. 2014. The Semiology Analysis in Media Studies: Roland Barthes' Approach. International Conference on Social Sciences and Humanities, Istanbul, 8-10 September 2014.

Callister, M. \& L. Stern 2007. The Role of Visual Hyperbole in Advertising Effectiveness. Journal of Current Issues and Research in Advertising 29,2: 1 - 14. https://doi.org/10.1080/10641734.2007.10505212

Chaouachi, S.G. \& K. Rached 2012. Perceived Deception in Advertising:

Proposition of a Measurement Scale. Journal of Marketing Research and Case Studies 12: 1 - 15. https://doi.org/10.5171/2012.712622

Chakraborty, A. \& R. Harbaugh 2014. Persuasive Puffery. Marketing Science 33,3: 382 - 400. https://doi.org/10.1287/mksc.2013.0826

Danciu, V. 2014. Manipulative Marketing: Persuasion and Manipulation of the Consumer through Advertising. Theoretical and Applied Economic 2,591: $19-34$.

Dike, S.C. 2015. Sustainable Environment, Economic Growth and Poverty Eradication Measures: The African Context: Why There is no Meeting Point. European Journal of Sustainable Development 4,2: 439 - 450. https://doi.org/10.14207/ejsd.2015.v4n2p439 
Dhlamini, L. 2017. Integrating Agenda 2030 for Sustainable Development Goals (SDGs) into Regional and National Development Plans and Strategies. Available at:

http://www.za.undp.org/content/south_africa/en/home/presscenter/article s/2017/01/20/integrating-agenda-2030-for-sustainable-developmentgoals-sdgs-into-regional-and-national-development-plans-and-strategiesby-lindiwe-dhlamini.html (Accessed 29 October 2017).

Fell, E. \& N. Lukianova 2015. Fast Food and the Semiotics of Gastronomy. ESSACHESS. Journal for Communication Studies 8,2: 59 - 73.

Fredericks, B. \& P. CroftWarcon 2014. Always 'Tasty', Regardless: Art, Chocolate and the Indigenous Australian. Journal of Media and Culture 17,1. Available at:

http://journal.media-culture.org.au/index.php/mcjournal/article/view/751 (Accessed on 19 October 2017).

Fyock, J. 2011. The Persuasiveness of Visual Hyperbole. The Pennsylvania State University Graduate School. Master's Dissertation.

Heath, T.P. \& A. Chatzidakis 2012. The Transformative Potential of Marketing from the Consumers' Point of View. Journal of Consumer Behaviour 11,4: 283 - 291. https://doi.org/10.1002/cb.1387

Huat, A.S. 2017. The Study of Visual Exaggeration in Fast Food Print Advertisements: An Insight into McDonald's Current Practices in Malaysia. Universiti Tunku Abdul Rahman, Masters' Thesis.

Kannan, R. \& S. Tyagi 2013. Use of Language in Advertisements. English for Specific Purposes in the World 13,37: 1 - 10.

Khan, A.I. \& A. Rajput 2014. Impact of Deceptive Advertising on Customer Behavior and Attitude: A Literature Viewpoint. Middle-East Journal of Scientific Research 21,1: 244 - 248.

https://doi.org/10.1111/mepo.12058

McQuarrie, E.F. \& B.J. Phillips 2005. Indirect Persuasion in Advertising: How Consumers Process Metaphors Presented in Pictures and Words. Journal of Advertising 34,2: 7 - 21.

Bhttps://doi.org/10.1080/00913367.2005.10639188

Nagler, M.G., 1993. Rather Bait than Switch: Deceptive Advertising with Bounded Consumer Rationality. Journal of Public Economics 51,3: 359 - 378.

https://doi.org/10.1016/0047-2727(93)90071-Z 
Oparinde, K.M. \& G.T. Agbede 2019. Visual Hyperbolism: A Semiotic Analysis of Fast Food Advertisements in South Africa. Interdisciplinary Journal of Economics and Business Law 8, Special Issue: 369 - 391.

Parsa, F.A. 2015. Visual Semiotics: How Still Images Mean. Interpreting Still Images by Using Semiotic Approaches. Unpublished paper.

Serva, C. 2017. Material Culture in Sociology: Definition, Studies and Examples. Available at: http://study.com/academy/lesson/materialculture-in-sociology-definition-studies-examples.html

(Accessed on 2 September 2017).

Shrum, L. J., M. Liu, M. Nespoli \& T.M. Lowrey 2012. Persuasion in the Marketplace: How Theories of Persuasion Apply to Marketing and Advertising. In Dillard, J. \& L. Shen (eds.): The Persuasion Handbook. California: Sage.

Tahmasbi, S. \& S.G. Kalkhajeh 2013. Critical Discourse Analysis: Iranian Banks' Advertisements. Asian Economic and Financial Review 3,1: 124 -145 .

Webster, M. 2016. The Merriam-Webster Dictionary. New Edition. Massachusetts: Merriam-Webster Inc.

Zhang, Y. 2015. The Impact of Brand Image on Consumer Behavior: A Literature Review. Open Journal of Business and Management 3: 58 - 62. https://doi.org/10.4236/ojbm.2015.31006

Kunle Musbaudeen Oparinde Institute for Systems Science Durban University of Technology $\underline{\text { KunleO@dut.ac.za }}$

Grace Temiloluwa Agbede Department of Media, Language and Communication Durban University of Technology agbedegrace@gmail.com 